\title{
Promoting Writing Competence and Positive Attitudes among College Students in a CLIL English Course
}

\author{
Sulaiman Alrabah ${ }^{1} \&$ Shu-hua $\mathrm{Wu}^{1}$ \\ ${ }^{1}$ Language Center, College of Business Studies, Public Authority for Applied Education and Training, Kuwait \\ Correspondence: Shu-hua Wu, Language Center, College of Business Studies, Public Authority for Applied \\ Education and Training, Kuwait. E-mail: wu104ohio@yahoo.com.tw
}

Received: October 15, 2016 Accepted: November 1, 2016 Online Published: January 12, 2017

doi:10.5539/ijel.v7n1p58 URL: http://dx.doi.org/10.5539/ijel.v7n1p58

\begin{abstract}
The study targeted a group of 27 students at a college in Kuwait who were enrolled in a Content and Language Integrated Learning (CLIL) English course during the academic year 2015-2016. The purpose of the study was to monitor students' assessments of their writing competence in English and to measure their attitudes toward the CLIL course. Data collection utilized a total of five focus-group interviews with the students which were recorded and transcribed, and a category system was generated to describe the commonalities in the participants' responses. Additionally, an online survey using Google Forms was based on the categories delineated from the interview data. The Microsoft Excel program was used for counting the means, standard deviations, and percentages for each of the survey items. The results of the study indicated that the majority of the students $(80 \%)$ thought that the CLIL course enhanced their writing competence both within and beyond the sentence level. Writing skills within the sentence level included the accurate use of punctuation marks and capitalization rules. Writing skills beyond the sentence level included paragraph organization, use of proper transition words, and writing cause-and-effect paragraphs. Approximately $20 \%$ of the students did not think CLIL improved their writing competence beyond the sentence level. Furthermore, the students displayed highly positive attitudes toward all aspects of the CLIL course. Implications were drawn for specialized teacher training to cope with the demands of CLIL courses, and longitudinal studies to track students' development of writing competence over time.
\end{abstract}

Keywords: content and language integrated learning (CLIL), language teaching methods, English writing competence, learner attitudes and motivation

\section{Introduction}

The introduction of the content and language integrated learning approach (CLIL) in the countries of the European Union was bound to influence other language teaching contexts in the world (Lasagabaster, 2008; Lasagabaster \& Sierra, 2010; Meyer, 2010). In the Far East, for example, English teachers in Japan, South Korea, Taiwan, and Hong Kong have conducted several studies to investigate CLIL and to compare its effectiveness to their traditional English as a Foreign Language (EFL) teaching methods (e.g., Bruton, 2011; Yamano, 2013; Yang \& Gosling, 2014; Yang, 2015). The CLIL approach represents an educational movement that has been promoted and brought to the attention of teachers and researchers in four different ways. First, the theoretical arguments proposed by Coyle, Hood, and Marsh (2010), and Dalton-Puffer (2011) went a long way to provide a convincing, common-sense rationale for the CLIL approach. When we as language teachers use the academic content the students are studying as the driving force of the content of our language classes, students will be more motivated to learn the content, and in the process, will be able to master more of the language as well. Another important dimension of the language learning process is affect. Krashen's (1985) "affective-filter" hypothesis proposed that students' affective states and the amount of stress they experience in class can impact to a great deal their receptivity and openness to the target language. In a CLIL class, where students feel more invested in the learning task because the content resembles academic content they encounter in their major classes, it would be safe to assume that their attitudes will be more positive than if the content consisted of mostly abstract linguistic rules and semantic meanings. Next, arguments for the benefits of implementing CLIL were bolstered by policy-makers, teachers, and parents alike (Hüttner, Dalton-Puffer, \& Smit, 2013; Gené-Gil, Juan-Garau, \& Salazar-Noguera, 2015). De Zarobe (2013), for example, reviewed CLIL implementation as a 
top-down movement from policy-makers to individual initiatives by teachers, parents, and school administrations in different European countries. Finally, there has been a considerable amount of research devoted to investigating not only the advantages of CLIL over the more traditional EFL classes, but also to the benefits of CLIL for students' linguistic competence in English as well as the more rapid rates of the students' competence in the skills of reading and writing English.

However, in the Middle East, with notable exceptions by Jawhar (2012) in Saudi Arabia, and Fahnestock (2011) in the United Arab Emirates, there has been a dearth of research studies conducted on CLIL implementation. This can be explained by the prevalence of centralized educational systems in the Arab world which tend to be conservative in adopting large-scale educational reforms at the state level. Nevertheless, due to CLIL's growing appeal as a language teaching approach, and as part of its continuous efforts at improving the English proficiency of its students, the English Department at the College of Nursing in Kuwait introduced a new CLIL English course during the academic year 2015-2016. The course adopted a theme-based curriculum design in which medical themes (e.g., surgical nursing) were employed as organizing principles for the content of the English course. In other words, the English language content was supplemented by the medical content from the students' major medical courses. Co-ordination between the course teacher and teachers from students' major departments consisted of weekly meetings with three major teachers to see what academic/medical contents they were covering each week in order to prepare the CLIL weekly lessons. The aim of the course was to increase the students' competence in academic/medical reading and writing in English as well as their content knowledge of medical information. Thus, the CLIL course was an academic English course organized around a specialized content of medical themes and issues.

Moreover, studies that have investigated CLIL's impact on students' writing competence have found advantages of CLIL classes over traditional EFL classes in promoting writing competence in English (Gené-Gil, Juan-Garau, \& Salazar-Noguera, 2015; Perez \& Ramiro, 2015). Thus, there was a need to conduct the present study to examine the impact of the CLIL course on the students' writing competence in English and to measure their attitudes toward the implementation of CLIL. The aims of the study were to measure students' assessments of their writing competence in English as an outcome of participating in the CLIL course, and to monitor their attitudes toward the integration of medical content and English language through CLIL. The study was conducted to search for answers for the following research questions:

1) What were the students' assessments of their competence in writing as a result of taking the CLIL course?

2) How did the integration of English instruction with medical content impact the students' attitudes toward the CLIL course?

\section{Review of the Literature}

This review is organized in four sections. The first section describes the context in which content and language learning (CLIL) was adopted at the college level in Kuwait. The second section addresses CLIL advantages in learning English. The third section reviews CLIL's potential impact on learners' written competence. The fourth section discusses studies of learners' attitudes toward CLIL courses.

\subsection{Context of the Study}

There are increasing demands by the medical profession worldwide for nursing professionals to have a high level of English proficiency in order to perform their tasks effectively in their workplaces (Ferguson, 2013). Similarly, the mission of the English Department at the College of Nursing in Kuwait is to produce students who have high proficiency in English. However, that mission was met with insurmountable obstacles due partly to the students' low performance in English at entry level, and partly to the students' poor performance in the courses offered at the college that employ English as the medium of instruction. Two factors led to the decision to adopt CLIL in the English course: (1) students' low levels of English proficiency at entry level, and (2) students' poor ratings of their English writing competence by the end of their English courses. Upon admission to the college, a large number of students entering the College of Nursing have not passed the required English Placement Test (EPT). According to Alotaibi, Aldaihani, and Alrabah (2014), "More than 70\% of the students who took the test in 2013-2104 failed to attain a passing score" (p. 441). These students' low proficiency levels in English was one of the factors that contributed to adopting CLIL for improving students' levels of proficiency in English. Moreover, findings from an evaluation study conducted by Aldaihani, Shuqair, Alotaibi, and Alrabah (2015) suggested that college-level students in Kuwait, by the end of their English courses, have poorly rated their writing competence in English. The researchers admonished teachers of English to devote more class time for teaching writing. There was a need, therefore, to look for new and innovative ways of language teaching and learning that could help students at the college level in Kuwait develop better writing skills than has been achieved so far. Furthermore, 
studies conducted by Hughes (2013), Perez and Ramiro (2015), Mungra (2010), and Whiiaker et al. (2011) have indicated that CLIL classes have proven advantages for developing students' writing competence over EFL classes. Therefore, CLIL was adopted as a teaching approach in which English language instruction was integrated with the study of academic content for developing students' English writing competence.

\subsection{CLIL Advantages}

CLIL has been defined by Coyle et al. (2010) as a dual-focused approach in which an additional language (e.g., English) is used for the teaching and learning of both content and language. Dalton-Puffer (2011) conducted a sweeping overview of CLIL issues and reported that one of the most important issues was related to the effect of CLIL on learners' linguistic outcomes. Comparisons of CLIL and EFL outcomes consistently showed improvements for CLIL students over EFL students not only in writing ability but also in speaking fluency and strategic competence in the target language. Furthermore, Lorenzo, Casal, and Moore (2010) argued that the focus on content in CLIL made communication in the classroom more relevant and purposeful as far as the students' immediate needs were concerned. CLIL was also touted to provide the language learning experience that is content-specific to the students' specializations and to encourage students' investment in the learning process. That was because the language was taught within a context which is related to students' specializations. However, Bruton (2011) argued for the need for classroom-based research to substantiate these claims. Leung (2005) previously stated, "The claims for or against bilingual education of any form ring hollow when there is not a clear sense of what happens inside the classroom" (p. 238). The claims about CLIL's effectiveness need to be, therefore, examined more closely in classroom-based studies. By restricting this review to data-based evidence, Bruton (2011) and Leung's (2005) recommendations were taken into account in the subsequent discussion of the impact of CLL on student's writing competence and students' attitudes toward CLIL.

\subsection{CLIL and Writing Competence}

Even though CLIL's effectiveness in promoting students' linguistic competence has attracted the interests of teachers and researchers worldwide, a few researchers have investigated CLIL's impact on students' written competence. For example, Mungra (2010) described how a CLIL designed course in Italy trained medical students to identify the basic components of medical abstracts in published research articles. The aim of the course was to train students to write abstracts of medical research articles. The researcher used rubrics to assess student writing abilities. Rubrics included medical factual knowledge of specific ailments as well as the English language required to report and write medical abstracts about these ailments. The aim of the study was to provide a model for CLIL courses that integrated medical content and English. The researcher also added a study-skills component to support students' schema formation of medical texts. While Mungra (2010) aimed to create a model for CLIL in English medical contexts, other research studies focused on languages other than English that were used as a medium of instruction in CLIL classes. Whittaker, Llinares, and McCabe (2011), for example, reported on a four-year longitudinal study of Spanish secondary school students' development of writing ability in English as an outcome of a CLIL course in European history. The researchers showed that the introduction of writing instruction worked as a scaffold that pushed the learners to generate written texts in English. In a similar fashion to Swain's (2005) "output hypothesis," the researchers viewed students' writing performance as learner output. Swain viewed learner speech in class as a necessary condition that helped learners move from processing language semantically to the syntactic processing of language. Hughes (2013), moreover, analyzed students' writing in a CLIL course in Contemporary Latin American Political Economy delivered in Spanish. His analysis was focused on the written performance of five students who were exposed to a full-length Spanish novel for the first time. They were asked to write their reflections on the course bulletin board. The results were considered by Hughes to challenge the grammar-oriented "focus on form" approach that characterizes many university-level CLIL courses. Hughes (2013), instead, argued for the importance of regular reading and writing, and social interaction to develop students' academic writing competence.

Some researchers have conducted comprehensive reviews of data-based evidence on the effectiveness of CLIL courses in promoting writing competence. For example, Dalton-Puffer (2011) reviewed studies on the effects of adopting CLIL on learners' linguistic outcomes and concluded that most such studies that used comparisons between CLIL and EFL classes consistently showed improvements for CLIL students over EFL students. Improvements occurred not only in writing development but also in speaking fluency and strategic competence in the target language. Nevertheless, Dalton-Puffer (2011) made the caveat that there were dimensions of writing that "reach beyond the sentence level that CLIL seemed to have little or no effect" (p. 187). However, Perez and Ramiro (2015) have focused their research study on the extent to which CLIL developed students' writing competence. They found evidence to suggest that CLIL writing classes in English were an effective means of teaching students on how to control written discourse beyond the sentence level. Perez and Ramiro employed 
text-genre analysis to study the written performance of a group of engineering students in a Spanish university who were taking a CLIL Chemistry course using English as the medium of instruction. The focus of the analysis was on students' degree of control of the (macro) textual-discourse features and the (micro) morphosyntactic features of a lab report. Their study determined that students from the CLIL writing class have outperformed EFL students in the acquisition of higher-ranked (macro) features of texts such as discourse markers which was interpreted by the researchers as a sign of good English writing beyond the sentence level. The question remains worthy of investigation as to whether CLIL classes can positively impact students' development of writing skills beyond the sentence level. While Dalton-Puffer (2011) suggested that CLIL classes have little or no effect on writing development beyond the sentence level, Perez and Ramiro (2015) showed CLIL had benefits on developing students' writing performance beyond the sentence level. Therefore, the present study targeted students' assessments of their writing competence in English after participating in the CLIL class. The data analysis for the first question of the study was focused on writing competence both within the sentence level such as the control of capitalization rules, punctuation and subject-verb agreement, and beyond the sentence level like the proper use of transition words and paragraph organization.

\subsection{Attitudes toward CLIL}

Sarnoff (1970) defined an attitude as "a disposition to react favorably or unfavorably to a class of objects" (p. 279). According to Marsh (2000), "A major outcome of CLIL is to establish not only competence in two languages, but also nurture a "can do" attitude toward language learning in general" (p. 10). Therefore, students' attitudes and motivation to learn have a role to play in CLIL. When a learner, for example, is actively involved in learning medical content through the medium of English, this can increase overall motivation toward learning the content itself. The medical content, being delivered in English, can have linguistic benefits to the learner. This can enhance content learning and the learner's positive attitude toward studying English and medicine together. Attitudes were the focus of numerous studies on CLIL. For example, Dafouz, Núñez, Sancho, and Foran (2007) conducted a study among Spanish university teachers and students to investigate their attitudes toward implementing CLIL in university level courses. They also measured students' and teachers' self-assessments of students' communicative competence in English after taking an advanced ESP course organized around content-specific areas of students' specializations including Chemistry, Health Sciences, and English Language and Linguistics. The respondents to the self-assessment questionnaire displayed positive attitudes to the implementation of CLIL courses at university level in Spain. Several CLIL studies have, moreover, measured the effectiveness of CLIL courses by comparing them to traditional EFL courses. For example, Lasagabaster and Sierra (2009) compared between students' attitudes toward learning English from a CLIL versus an EFL program. The researchers targeted a group of 287 Basque students in Spain and measured their attitudes toward English while controlling for the variables of gender, sociocultural status (i.e., the parents' level of education), age, and motivation to learn. The results all came in favor of the CLIL program on attitudes toward CLIL versus EFL classes. Lasagabaster (2011) further measured the correlation between the teaching approaches of CLIL and EFL and their effects on students' motivation to learn and their developing linguistic competence. The researcher pointed out the difficulty of relying on such a dynamic construct as motivation to learn because the subjects undergo change with the passage of time within the same individual learner. The results of the study, nevertheless, showed a slight advantage for adopting CLIL over EFL both in terms of student motivation and their overall proficiency in English.

The bulk of the research on CLIL, therefore, points to clear advantages for CLIL students over EFL students not only in linguistic and communicative competence, but also in more positive attitudes toward CLIL and their achievement in writing competence. Thus, the present study was conducted to monitor students' assessments of their writing competence in the CLIL course, and to measure the students' attitudes toward the implementation of CLIL at the college level.

\section{Methodology}

The study targeted a group of 27 students at the College of Nursing in Kuwait who were enrolled in a CLIL English course during the academic year 2015-2016. The research questions were focused on tapping the students' attitudes toward the CLIL course and their self-assessments of their writing competence in English. The methodology for collecting data to answer the first research question utilized Scheyder's (2012) two-pronged approach for measuring students' self-assessments of their writing competence: (1) the students' assessment of their own progress in the CLIL course as measured by their survey responses, and (2) the students' achievement in the CLIL course as measured by their final course grades. For the first measure of students' self assessments of their writing competence, categories of perceived student writing performance were generated by the researchers as an outcome of the focus-group interviews. These categories of writing performance were then put 
on likert-type statements in the survey with responses that ranged from strongly agree, agree, disagree, and strongly disagree. For the second measure, students' actual writing achievement was defined as their final grades in the CLIL course. Additionally, a solicitation letter was addressed to the participants assuring them of confidentiality and anonymity and informing them that their responses to the survey instrument were confidential and would not be shared with the CLIL course instructor.

In collecting evidence for the second research question, the researchers solicited the participants' attitudes toward CLIL as students who were exposed for the first time to the CLIL approach. Coyle et al. (2010) suggested the use of both questionnaires and group interviews to search for answers for questions related to attitudes. The data collection instruments were both an online survey and a total of five focus-group interviews. Data from the interviews were recorded and transcribed and a system of categories was generated by the researchers. The survey items were generated from the data of the interviews (Bazeley, 2013). The survey items were analyzed by Microsoft Excel software to generate percentages, means, and standard deviations. Numerical data reflected whether students were feeling they were making progress in English writing, and whether they had positive or negative attitudes toward the CLIL course.

\subsection{Data Collection}

Five focus-group interviews were conducted with 5 to 6 students each time with a total of 27 students. The interviews were first recorded and then transcribed by the researchers. The corpus of recorded interviews included 10 hours that were collected over a period of two months. The researchers then designed a "grounded survey" (Strauss \& Corbin, 1997) according to the data obtained from the interviews. In other words, the interviews were used by the researchers to search for commonalities among the participating students' attitudes and patterns of writing performance (Bazeley, 2013). These common patterns were used to generate the 16 items of the survey instrument. Then the survey was encoded on Google Forms for easy distribution through the students' mobile phones. From May to June, 2016, the survey was distributed among the students $(\mathrm{N}=27)$, where $\mathrm{N}$ represents the number of students who responded to the survey. There was 1 non-respondent to the survey, and the total respondent rate was $96.30 \%$.

\subsection{Data Analysis}

Interview data were separated into two major categories following the research questions of the study on students' assessments of writing competence and students' attitudes toward CLIL. Data analysis generated the common patterns and themes shared by the students to describe (1) their assessments of their writing competence in English and (2) their attitudes toward the CLIL classroom. The researchers generated categories to describe the common patterns in the data of the focus group interviews. The category system of the attitudes and writing competence was refined, and an inter-rater reliability check was conducted by the researchers to ensure a high degree of agreement of $95 \%$ on interpreting the responses to the survey items. Afterwards, the survey instrument was electronically posted to the participating students' smart phones, and as an outcome of responding to the survey items, the responses from each participant were recorded and tabulated into a spreadsheet. The Microsoft Excel software program was then employed to generate descriptive statistics including the means, standard deviations, and percentages for each of the survey's 16 items. Finally, tables were generated to display the numerical data for each of the two research questions of the study.

\section{Results}

The first research question was focused on students' assessments of their writing competence in English as a result of taking the CLIL course, and the second research question of the study was focused on tapping the students' attitudes toward the CLIL course. The survey and the focus-group interviews were the two main data sources of the study. Results for each question of the study were displayed as tables containing the relevant survey items along with researchers' notes from the interviews for further clarification when needed.

\subsection{Respondents' Assessments of Their Writing Competence}

Table 1 displays the means, standard deviations, and percentages of the students' responses to their self-assessments of their writing competence in English as a result of participating in the CLIL course. The survey items targeted the components of the writing skill that were taught in the course including writing within the sentence level such as capitalization, punctuation, and subject-verb agreement. The survey also included elements of the writing skill beyond the sentence level such as the use of transition words, paragraph organization, patient's case report, and cause-and-effect paragraphs. 
Table 1. Students' self-assessment of writing competence in the CLIL course

\begin{tabular}{|c|c|c|c|c|c|c|}
\hline \multirow[t]{2}{*}{ Language Skills } & \multirow[t]{2}{*}{ Means } & \multirow[t]{2}{*}{$\mathrm{SD}$} & \multicolumn{4}{|c|}{ Item Responses (\%) } \\
\hline & & & $\begin{array}{l}\text { Strongly } \\
\text { Agree }\end{array}$ & Agree & Disagree & $\begin{array}{l}\text { Strongly } \\
\text { Disagree }\end{array}$ \\
\hline 1. The course improved my writing competence in English. & 3.73 & 0.40 & 73.08 & 26.92 & 0.00 & 0.00 \\
\hline $\begin{array}{l}\text { 2. I am able to apply capitalization rules in my writing most } \\
\text { of the time. }\end{array}$ & 3.65 & 0.49 & 65.38 & 34.62 & 0.00 & 0.00 \\
\hline 3. I can correctly apply punctuation rules in my writing. & 3.58 & 0.58 & 61.54 & 34.26 & 3.85 & 0.00 \\
\hline 4. I can control subject-verb agreement in my sentences. & 3.27 & 0.72 & 46.15 & 38.46 & 15.38 & 0.00 \\
\hline $\begin{array}{l}\text { 5. I can use transition words (e.g., therefore) to organize my } \\
\text { ideas in writing. }\end{array}$ & 3.42 & 0.81 & 57.69 & 30.77 & 7.69 & 3.85 \\
\hline $\begin{array}{l}\text { 6. I am able to apply paragraph organization to write topic } \\
\text { sentences, supporting sentences, and concluding sentences. }\end{array}$ & 3.38 & 0.80 & 53.85 & 34.62 & 7.69 & 3.85 \\
\hline $\begin{array}{l}\text { 7. I can write a patient's case report (e.g., medical history) in } \\
\text { English. }\end{array}$ & 3.50 & 0.58 & 53.85 & 42.31 & 3.85 & 0.00 \\
\hline 8. I am able to write a cause-and-effect paragraph in English. & 2.96 & 0.96 & 34.62 & 38.46 & 23.08 & 3.85 \\
\hline
\end{tabular}

A general observation that the data analysis produced was that students rated their writing skills within the sentence level higher than their writing skills beyond the sentence level. This meant that the majority of the students were ready to acquire the writing skills within the sentence level such as capitalization, punctuation, and subject-verb agreement. Some of the students, however, have not yet developed in the language enough to acquire the writing skills beyond the sentence level such as paragraph organization, cohesion, or writing cause-and-effect paragraphs. In order to avoid any potential bias in students' self-assessments of their writing competence, group interviews explored further the students' perceptions of their writing abilities (Coyle et al., 2010). During the group interviews, the students explained that they probably needed more time to practice and control writing skills beyond the sentence level. This meant that the students' writing skills were developing as a result of participating in the CLIL course.

\subsubsection{Writing Skills within the Sentence Level}

Data analysis of students' assessments of their writing competence within the sentence level focused on their control of capitalization rules, punctuation rules, and subject-verb agreement. Item 1 targeted the students' assessments of their overall writing competence in English. The results for item $1(\mathrm{M}=3.73, \mathrm{SD}=0.40)$ indicated that most of the students agreed their writing competence had improved as a result of taking the CLIL course. More specifically, $73.08 \%$ of the students strongly agreed they had made progress in English writing, and 26.92\% of the students agreed that the course improved their writing ability in English.

Item 2 focused on the basic writing skill of capitalization at the beginning of each sentence, and of proper names, places, and the pronoun "I." Students' responses $(\mathrm{M}=3.65, \mathrm{SD}=0.49)$ showed that they were able to control capitalization rules in their English writing. In fact, while $65.38 \%$ of the students strongly agreed they could control capitalization rules, $34.62 \%$ of the students agreed they can apply these rules in their English writing. Interview data revealed that the students believed these rules to be essential for writing in English.

Item 3 focused on the students' sense of control of punctuation rules in their writing. The responses $(M=3.58$, $\mathrm{SD}=0.58)$ showed the students' self-assessments of their control of punctuation rules was high. For example, $61.54 \%$ of the students strongly agreed they could control punctuation rules, while $34.62 \%$ of the students agreed they knew how to apply punctuation rules in English.

Item 4 targeted subject-verb agreement. The course focused on teaching this aspect of grammar-related writing because the students not only needed to develop fluency in writing, but also accuracy in conveying their ideas in writing. As a result of the course focus, students' responses $(\mathrm{M}=3.27, \mathrm{SD}=0.72)$ showed that $46.15 \%$ of the students strongly agreed and $38.46 \%$ of the students agreed they could control subject-verb agreement in their writing. $15.38 \%$ of the students disagreed that they can control subject-verb agreement in their writing. Interview data revealed that students mostly used this skill when revising their writing. Most students expressed the view that they needed to get their ideas first even though there maybe errors in subject-verb agreement. However, they corrected subject-verb agreement when they made their final revisions before submitting their papers to the instructor.

\subsubsection{Writing Skills beyond the Sentence Level}

Item 5 was focused on transition words and the students' ability to use them for the logical presentation of ideas 
in English writing. Students' responses $(\mathrm{M}=3.42, \mathrm{SD}=0.81)$ indicated that they felt they could use transition words as a writing skill in their English writing. As a matter of fact, $57.69 \%$ of the students assessed themselves to be capable of applying transition words in their English writing, and $30.77 \%$ of the students have agreed that they could use transition words and connecting devices correctly. However, $7.69 \%$ of the students disagreed and $3.85 \%$ strongly disagreed that they could use transitions words correctly.

Item 6 targeted the skill of organization in paragraph writing. Having been exposed throughout the course to topic sentences, supporting sentences, and concluding sentences, the students were expected to produce these kinds of sentences in their writing. Students' responses $(\mathrm{M}=3.38, \mathrm{SD}=0.80)$ indicated same variations in their assessments of their ability to produce these sentences in their English writing. While $53.85 \%$ of the students strongly agreed and $34.62 \%$ of them agreed they could control these sentences, $7.69 \%$ of the students disagreed and $3.85 \%$ of them strongly disagreed they controlled topic, supporting, and concluding sentences. These variations were to be expected because, in many ways, paragraph organization is the culmination of the paragraph writing skill in English.

Item 7 asked whether the students assessed themselves to be able to write an extended paragraph containing a patient's case report. Students' responses $(\mathrm{M}=3.50, \mathrm{SD}=0.58)$ indicated that there was same variation in their assessment of their ability to perform this writing task. While $53.85 \%$ of the students strongly agreed and $42.31 \%$ agreed that they felt confident about their ability to write a patient's case report including a medical history in English, 3.85\% of the students disagreed. These results indicated that this writing task still posed some challenges for a minority of the students. However, the majority felt they were able to perform this writing task.

Item 8 inquired about the students' self-assessment of their ability to write a cause-and-effect paragraph in English. It is worth noting that producing a well developed cause-and-effect paragraph requires that the student already controls all the writing skills within and beyond the sentence level needed to write such as capitalization, punctuation, subject-verb agreement, transition words, and paragraph organization. Responses $(\mathrm{M}=2.96$, $\mathrm{SD}=0.96$ ) showed this type of paragraph was the most challenging to the students to control. $34.62 \%$ of the students strongly agreed and $38.46 \%$ of them agreed they could write a cause-and-effect paragraph. However, $23.08 \%$ of the students disagreed and $3.85 \%$ of them strongly disagreed that they could write a cause-and-effect paragraph.

The results of the first question revealed that the majority of the students $(80 \%)$ thought the CLIL course enhanced their writing competence both within and beyond the sentence level, and approximately $20 \%$ of the students did not think CLIL improved their writing competence beyond the sentence level. Finally, upon looking at the students' end-of-term course grades, the researchers found a high degree of consistency between students' self-assessments of their writing competence, and their actual end-of-term course grades. This meant that the students as a group have not over-assessed their writing competence.

\subsection{Attitudes toward CLIL}

Table 2 displays the eight survey items devoted to measure the students' attitudes toward aspects of the CLIL course they encountered in class. Aspects of the CLIL course included the students' attitudes toward learning the components of medical words, reading passages, medical charts, case reports, and learning English from medical texts. Most of the responses showed that the respondents either strongly agreed or agreed with the 8 solicited items which meant they displayed overall positive attitudes toward the CLIL course. 
Table 2. Attitudes toward integrating content to learning academic English

\begin{tabular}{|c|c|c|c|c|c|c|}
\hline \multirow{2}{*}{$\begin{array}{l}\text { Attitudes toward Content and Language } \\
\text { Integrated Learning }\end{array}$} & \multirow[t]{2}{*}{ Means } & \multirow[t]{2}{*}{ SD } & \multicolumn{4}{|c|}{ Item Responses (\%) } \\
\hline & & & $\begin{array}{l}\text { Strongly } \\
\text { Agree }\end{array}$ & Agree & Disagree & $\begin{array}{l}\text { Strongly } \\
\text { Disagree }\end{array}$ \\
\hline $\begin{array}{l}\text { 1. The CLIL English course helped me identify the basic } \\
\text { components of medical words (i.e., roots, prefixes, and suffixes). }\end{array}$ & 3.81 & 0.40 & 77.78 & 18.52 & 0.00 & 0.00 \\
\hline $\begin{array}{l}\text { 2. Reading medical passages helped me grasp the meaning of } \\
\text { medical words in my major courses. }\end{array}$ & 3.65 & 0.69 & 73.08 & 23.08 & 0.00 & 3.85 \\
\hline $\begin{array}{l}\text { 3. Being taught how to read medical charts in English helped me in } \\
\text { my major courses. }\end{array}$ & 3.77 & 0.43 & 76.92 & 23.08 & 0.00 & 0.00 \\
\hline $\begin{array}{l}\text { 4. The CLIL English course taught me how to write a patient's case } \\
\text { report similar to my major courses. }\end{array}$ & 3.58 & 0.50 & 74.07 & 23.08 & 0.00 & 0.00 \\
\hline $\begin{array}{l}\text { 5. Introducing medical content in the CLIL English course } \\
\text { strengthened my knowledge of the major courses. }\end{array}$ & 3.69 & 0.47 & 69.23 & 30.77 & 0.00 & 0.00 \\
\hline $\begin{array}{l}\text { 6. I was motivated to learn because I felt the content was relevant } \\
\text { to my studies. }\end{array}$ & 3.50 & 0.65 & 57.69 & 34.62 & 7.69 & 0.00 \\
\hline $\begin{array}{l}\text { 7. Integrating medical content into the CLIL English course was } \\
\text { beneficial to my English. }\end{array}$ & 3.77 & 0.43 & 76.92 & 23.08 & 0.00 & 0.00 \\
\hline $\begin{array}{l}\text { 8. Routine tests strengthened what I have learned and gave me } \\
\text { feedback on my progress in learning academic English. }\end{array}$ & 3.81 & 0.40 & 80.77 & 19.23 & 0.00 & 0.00 \\
\hline
\end{tabular}

\subsubsection{Attitudes toward Medical Words}

The most positive attitudes were displayed by the students toward the components of medical words (i.e., prefixes, roots, and suffixes). The statistics for item $1(\mathrm{M}=3.81, \mathrm{SD}=0.40)$ showed the students all agreed that this was one of the most prominent aspects of the course that they liked. Students used the components of medical words to understand their meanings. The lexical information found in the prefixes, roots, and suffixes of medical words is highly-regularized. For example, the suffix "-scopy" means internal physical examination. It is useful in knowing the meaning of a range of medical procedures such as colonoscopy (examination of the colon), endoscopy (internal examination), and laparoscopy (examination of the abdominal area). Therefore, the students felt positive toward the introduction of medical word components. They felt empowered to know these kinds of information which helped them understand the meanings of medical words. The majority of the students (77.78\%) strongly agreed and $18.52 \%$ of the students agreed that word components were an important part of the course. During their focus-group interviews, the students said they recognized the medical words in reading passages because the CLIL course taught them how to understand English word components.

Item 2 sought the students' attitudes toward reading highly-specialized medical passages about different types of diseases. The purpose of introducing these passages was to provide students with opportunities to understand medical word components in context. The results for item $2(\mathrm{M}=3.65, \mathrm{SD}=0.69)$ indicated that the students agreed that the reading lessons provided them with the chance to infer the meanings of medical words in extended reading passages. The majority of the students (73.08\%) strongly agreed and $23.08 \%$ also agreed that encountering medical words in a medical reading passage was another positive aspect of the CLIL course.

\subsubsection{Attitudes toward Reading Medical Charts and Writing a Patients' Case Report}

The students also held positive attitudes toward reading patients' medical charts. Reading medical charts accurately involves knowing medical acronyms and treatment procedures that had been prescribed by the attending doctor. Also the students needed to know the signs and symptoms of different ailments, family history, present complaints, examinations, diagnosis, and treatment. The results for item $3(\mathrm{M}=3.77, \mathrm{SD}=0.43)$ showed that this skill was deemed important for nursing students which basically means to know how to read and correctly interpret someone's medical chart. $76.92 \%$ of the students strongly agreed with this item, while $23.08 \%$ agreed.

Moreover, the students displayed mostly positive attitudes toward writing a patient's case report. The results for item $4(\mathrm{M}=3.58, \mathrm{SD}=0.50)$, however, showed that the students were not as positive about writing reports as reading medical charts. This can probably be explained by the differences between the receptive skill of reading which is relatively easier than the more demanding productive skill of writing. Also the fact that $74.07 \%$ of the students strongly agreed and the rest $23.08 \%$ agreed with this item showed that even though writing a patient's case report may be challenging for, at least, some of them, the majority were in favor of including writing a patient's case report in the course. 


\subsubsection{Attitudes toward Incorporating Medical Content in the English Course}

Item 5 solicited students' attitudes toward incorporating medical content in the English course which meant the CLIL course strengthened their knowledge of their major courses. The results for item $5(\mathrm{M}=3.69, \mathrm{SD}=0.47)$ indicated the students felt this course reinforced their exposure to medical facts, and that taking a CLIL course strengthened their knowledge of their major courses. $69.23 \%$ of the students strongly agreed while $30.77 \%$ of the students agreed they had positive attitudes toward integrating medical content into the English course.

Item 6 was focused on integrating content into the English course which was encouraging for the students to keep learning new content from the course. The results for item $6(\mathrm{M}=3.50, \mathrm{SD}=0.65)$ showed that not all the students held positive attitudes toward being motivated to learn. $57.69 \%$ of the students strongly agreed and $34.62 \%$ of the students agreed that the challenging medical content helped them feel motivated to learn. A small minority $7.69 \%$ of the students, however, have disagreed with item 6 .

Item 7 asked students whether they agreed that integrating medical content in the course was, in fact, beneficial to their English. This item meant that CLIL worked to strengthen students not only in their content areas but also in English as the target language. The students' responses to item $7(\mathrm{M}=3.77, \mathrm{SD}=0.43)$ indicated that most students favored integrating medical content and language learning. The distribution according to item responses also showed that $76.92 \%$ of the students strongly agreed, and $23.08 \%$ agreed with this item.

Item 8 solicited students' attitudes toward the routine tests that came in the course. The fact that tests assessed not only the students' English knowledge, but also their grasp of the medical knowledge that was discussed in the course was seen positively by the students. The results for item $8(\mathrm{M}=3.81, \mathrm{SD}=0.40)$ meant this item had the most positive attitudes among the students. $80.77 \%$ of the students strongly agreed and $19.23 \%$ agreed to item 8 . Interview data, moreover, revealed that the students felt positive about the routine tests taken in the course. Students reported that they got good feedback about their learning of English and medical content through the tests. In other words, routine tests had a good wash back effect because they alerted students to identify relevant information in the course that may come in future tests. So, even if they did not do well in one test, they could focus their efforts on the material that came in that test. In general, subsequent tests reinforced previous tests, and so on.

\subsection{Conclusions}

The findings of the study indicated that the students assessed that their writing skills in English have improved as an outcome of participating in the CLIL course. They assessed that the improvements have impacted their writing skills within the sentence level such as punctuation marks, capitalization rules, and subject-verb agreement. However, there was variation among students' assessment of writing skills beyond the sentence level such as paragraph organization, use of proper transition words, as well as writing patients' case reports, and cause-and-effect paragraphs. Moreover, the students displayed overall positive attitudes toward having participated in the CLIL course. They also had favorable attitudes toward all aspects of the course such as teaching the components of medical words (e.g., prefixes, roots, and suffixes), reading patients' medical charts and case reports, and the routine tests of the course.

\section{Implications for Pedagogy}

Due to the fact that a CLIL course may require the English teacher to know more about a discipline that may be demanding or unfamiliar, there is a need for teacher training of English teachers in their students' major content areas. Training needs to adopt a specialized curriculum organized around workshops and introductory courses in each major department. The major departments need to identify the learning outcomes of their graduates, so English teachers can explore the knowledge and skills they need to integrate in their language curriculums. Moreover, upon an English teacher's choice to teach a CLIL course, there is a need for co-ordination and close co-operation with teachers from the students' major departments. Course plans may be exchanged to ensure coherence between the specialized content the English teacher is covering and the corresponding knowledge and skills students are learning in the major courses.

\section{Implications for Future Research}

There is a need for more research on students' development of writing competence in CLIL courses. The present study found variation in students' assessments of their writing competence in English. The majority thought CLIL helped improve their writing skills both within and beyond the sentence level. However, a minority of the students thought CLIL did not help their writing competence beyond the sentence level. This variation indicated that the students needed more time to acquire these more complex skills of writing. Given more time to practice these skills, the students will gradually be able to master them and reach a high level of writing development in English. Due to the developmental nature of the emergence of writing competence, a longitudinal design is 
recommended. More specifically, students learning how to write English need to go through the stage of the "within-the-sentence" mechanics of writing such as punctuation marks, capitalization rules, and subject-verb agreement. At a more advanced level, students move to a more advanced stage in which they begin to control writing "beyond-the-sentence" level. These conventions include extended reports and narrative, descriptive, persuasive, and cause-and-effect paragraphs. This process of development in writing in a second language may very well take longer than one academic year. Therefore, a longitudinal design is well-suited for the study of developing writing competence over time.

\section{References}

Aguilar, M., \& Rodríguez, R. (2012). Lecturer and student perceptions on CLIL at a Spanish university. International Journal of Bilingual Education and Bilingualism, 15(2), 183-197. http://dx.doi.org/10.1080/13670050. 2011.615906

Aldaihani, H. A., Shuqair, K. M., Alotaibi, A. M., \& Alrabah, S. (2015). Students' perceptions of the effectiveness of the English program taught at the College of Technological Studies in Kuwait. English Language Teaching, 8(4), 80-89. https://doi.org/10.5539/elt.v8n4p80

Alotaibi, A. M., Aldaihani, H. A., \& Alrabah, S. (2014). An investigation of the factors which contribute to low English achievement in secondary schools, as perceived by Kuwaiti and non-Kuwaiti English teachers. European Scientific Journal, 10(25), 440-459.

Bazeley, P. (2013). Qualitative data analysis: Practical strategies. Thousand Oakes: Sage Publications.

Bruton, A. (2011). Are the differences between CLIL and non-CLIL groups in Andalusia due to CLIL? A reply to Lorenzo, Casal and Moore (2010). Applied Linguistics, 32(2), 236-241. https://doi.org/10.1093/applin/amr007

Bruton, A. (2011). Is CLIL so beneficial, or just selective? Re-evaluating some of the research. System, 39(4), 523-532. https://doi.org/10.1016/j.system.2011.08.002

Coyle, D., Hood, P., \& Marsh, D. (2010). Content and language integrated learning. New York: Cambridge University Press.

Dafouz, E., Núñez, B., Sancho, C., \& Foran, D. (2007). Integrating CLIL at the tertiary level: Teachers' and students' reactions. Diverse Contexts-converging goals. CLIL in Europe, 91-101. Frankfurt: Peter Lang.

Dalton-Puffer, C. (2011). Content-and-language integrated learning: From practice to principles?. Annual Review of Applied Linguistics, 31, 182-204. http://dx.doi.org/10.1017/S0267190511000092

De Zarobe, Y. R. (2013). CLIL implementation: From policy-makers to individual initiatives. International Journal of Bilingual Education and Bilingualism, 16(3), 231-243. http://dx.doi.org/10.1080/13670050

Fahnestock, N. (2011). EFL female Emirati students' perception of the use of an interactive Mathematics software program in a CLIL class at the tertiary level (Unpublished doctoral thesis). University of Exeter, UK. Retrieved from http://hdl.handle.net/10036/3531

Ferguson, G. (2013). English for medical purposes. In B. Paltridge \& S. Starfield (Eds.), The handbook of English for specific purposes (pp. 243-261). Chichester, UK: John Wiley \& Sons, Ltd. http://dx.doi.org/10.1002/9781118339855

Gené-Gil, M., Juan-Garau, M., \& Salazar-Noguera, J. (2015). Writing development under CLIL provision. In M. Juan-Garau \& J. Salazar-Noguera (Eds.), Content-based language learning in multilingual educational environments (pp. 139-161). Cham, Switzerland: Springer International Publishing. https://doi.org/10.1007/978-3-319-11496-5_9

Hughes, N. (2013). Developing academic register in CLIL: An exploratory study of Spanish L2 students' Latin American Political Economy writing in the UK. Latin American Journal of Content and Language Integrated Learning, 6(2), 42-71. http://dx.doi.org/10.5294/laclil.2013.6.2.3

Hüttner, J., Dalton-Puffer, C., \& Smit, U. (2013). The power of beliefs: Lay theories and their influence on the implementation of CLIL programs. International Journal of Bilingual Education and Bilingualism, 16(3), 267-284. http://dx.doi.org/10.1080/13670050.2013.777385

Jawhar, S. (2012). Conceptualizing CLIL in a Saudi context: a corpus linguistic and conversation analytic perspective (Unpublished doctoral thesis) Newcastle University, UK. Retrieved from http://hdl.handle.net/10443/1849 
Krashen, S. D. (1985). The input hypothesis: Issues and implications. New York: Addison-Wesley Longman.

Lasagabaster, D. (2008). Foreign language competence in content and language integrated courses. Open Applied Linguistics Journal, 1, 31-42. https://doi.org/10.2174/1874913500801010030

Lasagabaster, D. (2011). English achievement and student motivation in CLIL and EFL settings. Innovation in Language Learning and Teaching, 5(1), 3-18. http://dx.doi.org/10.1080/17501229.2010.519030

Lasagabaster, D., \& Sierra, J. M. (2009). Language attitudes in CLIL and traditional EFL classes. International CLIL Research Journal, 1(2), 4-17. Retrieved from http://www.icrj.eu/index.php?vol=12\&page=73

Lasagabaster, D., \& Sierra, J. M. (2010). Immersion and CLIL in English: More differences than similarities. ELT Journal, 64(4), 367-375. http://dx.doi.org/10.1093/elt/ccp082ccp082.

Leung, C. (2005). Language and content in bilingual education. Linguistics and Education, 16(2), 238-252. https://doi.org/10.1016/j.linged.2006.01.004

Lorenzo, F., Casal, S., \& Moore, P. (2010). The effects of content and language integrated learning in European education: Key findings from the Andalusian bilingual sections. Evaluation Project. Applied Linguistics, 20(11), 1-25. https://doi.org/10.1093/applin/amp041

Marsh, D. (2000). Using languages to learn and learning to use languages. Finland, University of Jyväskylä.

Meyer, O. (2010). Towards quality CLIL: Successful planning and teaching strategies. Pulso: Revista de Educación, 33, 11-29.

Mungra, P. (2010). Teaching writing of scientific abstracts in English: CLIL methodology in an integrated English and Medicine course. Ibérica, 20, 151-166.

Perez, M. D. M. S., \& Ramiro, M. S. S. (2015). Writing professional genres in a second language: Results from a Spanish university CLIL context. American Journal of Educational Research, 3(5), 576-580. http://dx.doi.org/10.12691/education-3-5-7

Riddlebarger, J. (2013). Doing CLIL in Abu Dhabi. Asian EFL Journal, 15(4), 413-421.

Sarnoff, I. (1970). Social attitudes and the resolution of motivational conflict. In M. Jahoda \& N. Warren (Eds.), Attitudes: Selected readings (pp. 279-284). Harmondsworth: Penguin.

Scheyder, E. C. (2012). The impact of recordings on student achievement in critical language courses. (Doctoral dissertation). University of Pennsylvania, U.S.A.

Strauss, A., \& Corbin, J. M. (Eds.). (1997). Grounded theory in practice. Thousand Oaks, CA: Sage.

Swain, M. (2005). The output hypothesis: Theory and research. In E. Hinkel (Ed.), Handbook of research in second language teaching and learning (vol. 1, pp. 471-483). Mahwah, NJ: Lawrence Erlbaum Associates.

Whittaker, R., \& Llinares, A. (2009). CLIL in social science classrooms: Analysis of spoken and written productions. In Y. R. de Zarobe \& R. M. Catalán (Eds.), Content and language integrated learning: Evidence from research in Europe (pp. 215-234). Toronto: Multilingual Matters.

Whittaker, R., Llinares, A., \& McCabe, A. (2011). Written discourse development in CLIL at secondary school. Language Teaching Research, 15(3), 343-362. http://dx.doi.org/10.1177/1362168811401154

Yamano, Y. (2013). CLIL in a Japanese primary school: Exploring the potential of CLIL in a Japanese context. International CLIL Research Journal, 2(1), 19-30. htttp://www.icrj.eu/21/article2.html

Yang, W. (2015). Content and language integrated learning next in Asia: Evidence of learners' achievement in CLIL education from a Taiwan tertiary degree program. International Journal of Bilingual Education and Bilingualism, 18(4), 361-382. http://dx.doi.org/10.1080/13670050.2014.904840

Yang, W., \& Gosling, M. (2014). What makes a Taiwan CLIL program highly recommended or not recommended? International Journal of Bilingual Education and Bilingualism, 17(4), 394-409. http://dx.doi.org/10.1080/13670050.2013.808168

\section{Copyrights}

Copyright for this article is retained by the author(s), with first publication rights granted to the journal.

This is an open-access article distributed under the terms and conditions of the Creative Commons Attribution license (http://creativecommons.org/licenses/by/4.0/). 